\title{
Comparison of metabolic rates among macrophyte and nonmacrophyte habitats in streams
}

\author{
Anette Baisner Alnoee ${ }^{1,3}$, Tenna Riis ${ }^{1,4}$, and Annette Baattrup-Pedersen ${ }^{2,5}$ \\ ${ }^{1}$ Department of Bioscience, Aarhus University, Ole Worms Allé 1, DK-8000 Aarhus, Denmark \\ ${ }^{2}$ Department of Bioscience, Aarhus University, Vejlsøvej 25, DK-8600 Silkeborg, Denmark
}

\begin{abstract}
Little is known about the relative contribution of different stream habitats to reach-scale metabolism. We measured in situ metabolism in sand, gravel, stone, and macrophyte habitats to compare metabolic rates among these habitat types and to compare habitat-weighted measurements with reach-scale measurements. We used open-bottom chambers in sand, gravel, and macrophyte habitats and closed-bottom chambers in stones, and we estimated reach-scale metabolism from 2-station $\mathrm{O}_{2}$ budgets. Macrophyte habitats had a significantly higher gross primary production (GPP) and community respiration (CR) than stone, gravel, and sand habitats. A large part of this difference was associated with epiphytic biofilm: $28 \%$ of net ecosystem production (NEP), $20 \%$ of CR, and 24\% of GPP. Macrophyte habitats contributed proportionally more to reach-scale metabolism than did the other habitat types. Forty-one percent of reach-scale NEP, $60 \%$ of ecosystem respiration (ER), and $50 \%$ of GPP were associated with this habitat type even though only $14 \%$ of the reach was covered by macrophytes. We found significant linear relationships between GPP and CR and the amount of autotrophic biomass in the streams. The rates reported in 11 literature studies fit into our observed relationships, showing the generality of our findings. The rates we obtained expand the range of reported metabolic values in relation to autotrophic biomass for both low and high biomass. The importance of macrophyte habitat can be ascribed to the macrophytes themselves, the associated epiphytic biofilm, and the fine organic material trapped in the dense stands. We conclude that besides having an effect on the structural elements in streams, macrophytes contribute significantly to stream ecosystem functions.
\end{abstract}

Key words: benthic metabolism, autotrophic biomass, Ranunculus aquatilis, epiphytic metabolism, stream metabolism, primary production

Ecosystem production and respiration are functions that are related directly to energy flows within the ecosystem. Measurements of metabolism provide information about these functions in the form of gross primary production (GPP), which expresses the total $\mathrm{C}$ fixed, and ecosystem respiration (ER), which expresses the total amount of organic matter respired in the ecosystem. In general, if ER > GPP, the stream is heterotrophic, whereas if GPP > ER, the stream is autotrophic.

Comparisons of GPP and ER over spatial and temporal scales provide knowledge on how physicochemical and biotic variables affect energy flow. Structural properties, in terms of physical and chemical conditions controlled by hydrological and geomorphological conditions, and the presence and abundance of autotrophic and heterotrophic organisms affect stream metabolism directly and indirectly because they may act as stressors or facilitators on the metabolism of other organisms. Stream canopy cover controls stream metabolism via the combined effects of light availability and allochthonous supply of detritus (Bernot et al. 2010, Clapcott and Barmuta 2010). Furthermore, across biomes, reach-scale GPP is related to light availability as a descriptor of autotrophic biomass (i.e., periphyton), whereas ER is related to water P concentration and the extent of depositional areas for organic matter within the reach (Mulholland et al. 2001). The effect of autotrophic biomass on reach-scale GPP and ER was demonstrated in a Swiss stream where GPP and ER decreased up to 70\% after $90 \%$ of the macrophytes was removed (Kaenel et al. 2000). In addition to their effect on reach-scale metabolism, macrophytes can be large 3-dimensional structures capable of changing current velocity and sediment composition (Sand-Jensen 1998, Kleeberg et al. 2010) and adding to the physical complexity of streams.

Studies on habitat-specific metabolism in streams generally are based on in-stream or at-stream measurements of changes in dissolved $\mathrm{O}_{2}$ (DO) in chambers. In-stream measurements done in open-bottom chambers embed-

E-mail addresses: ${ }^{3}$ anette.alnoee@bios.au.dk; ${ }^{4}$ tenna.riis@bios.au.dk; ${ }^{5}$ abp@bios.au.dk

DOI: 10.1086/687842. Received 12 August 2015; Accepted 22 March 2016; Published online 12 July 2016.

Freshwater Science. 2016. 35(3):834-844. (c) 2016 by The Society for Freshwater Science. 
ded in the stream bed include hyporheic metabolic processes (Fellows et al. 2006), whereas closed-bottom chambers placed in the stream (e.g., Reid et al. 2006, Aristegi et al. 2010, Acuña et al. 2011) include only the metabolism of the components inside the chamber. At-stream chambers are placed at the stream bank but with continuous renewal of stream water in the chambers throughout the experimental period (Prahl et al. 1991).

Effects of macrophytes on stream metabolism have been assessed by measuring reach-scale metabolism from 1- or 2-station measurements (e.g., Marzolf et al. 1994, Young et al. 1998) or in the laboratory (Van et al. 1976, Binzer et al. 2006). However, measurements at the reachscale give no information on how different types of habitat contribute to reach-scale metabolism. Habitat-specific metabolism in streams has been studied in sand, gravel/ cobble, and stone habitats (e.g., Bott et al. 1985, Fellows et al. 2001, Aristegi et al. 2010), whereas fewer investigators have studied habitat-specific metabolism in macrophyte habitats (but see Prahl et al. 1991, Acuña et al. 2011, Leggieri et al. 2013) despite their dominant role in many lowland streams. Koopmans and Berg (2015) reported an eddy covariance technique for studying stream metabolism at the habitat scale, but this technique has not yet been tested in macrophyte beds.

Measuring habitat metabolism in chambers has several disadvantages. First, when in-stream or at-stream closed chambers are used, the hyporheic zone, which may contribute significantly to metabolism (Fellows et al. 2001), is excluded. Second, supersaturation of $\mathrm{CO}_{2}$ or $\mathrm{O}_{2}$ or nutrient limitation can develop in the chambers because they are closed systems. This problem can be avoided by limiting the incubation time. Third, when measuring habitat metabolism in chambers, potential hotspots in the reach can be overlooked. For instance, leaf packs, amphibious vegetation, or macrophytes, which could contribute significantly to the reach-scale metabolism, might cover only a small area of the reach. Macrophytes can be potential hotspots because they have high autotrophic biomass, large deposits of fine organic sediments in the beds (SandJensen 1998, Kleeberg et al. 2010), roots that respire, and surface area that acts as substrate for epiphytic biofilm.

We measured metabolism in stream habitats dominated by stone, gravel, sand, and macrophytes to estimate the proportional contribution of these typical lowland-stream habitats to reach-scale metabolism. We used open-bottom chambers except when measuring metabolism on stone habitats, where we used closed-bottom chambers. The specific aims of our study were to: 1) measure in situ metabolic rates in stream habitats dominated by stone, gravel, sand, and macrophytes, 2) quantify the contribution of habitat metabolism to reach-scale metabolism, 3) estimate the contribution of epiphytic biofilm to macrophyte habitat metabolism, 4) identify predictors of habitat metabolism, and 5) compare habitat metabolism among a range of stream types reported in the literature to evaluate more generally the role of macrophyte habitats as potential metabolic hotspots. We hypothesized that macrophyte habitats would have higher metabolic rates/stream area because of higher standing biomass and contributions from epiphytic biofilm. Furthermore, metabolism and biomass are highly correlated, so we expected that autotrophic biomass would be one of the main predictors of habitat metabolism.

\section{METHODS}

\section{Study sites and stream characteristics}

We conducted our study at 2 temperate Danish lowland streams, Linå and Skader. The study reach at Linå is $2^{\text {nd }}$-order and meandering with high occurrence of submerged macrophytes, whereas the study reach at Skader is $3^{\text {rd }}$-order with limited occurrence of submerged macrophytes. We placed 100 evenly distributed transects perpendicular to the stream bank in each 500-m-long experimental reach. At each transect, we measured stream width, depth at 5 equidistant points along the transect, and cover of benthic substrates and macrophyte species. The substrates were stone, gravel, sand, and mud. We calculated cover (\%) of each substrate type and macrophytes at the reach scale as relative frequency at all examined points and estimated areal cover $\left(\mathrm{m}^{2}\right)$ by scaling relative cover to the whole reach area.

We estimated average reach-scale water velocity in 2 representative $100-\mathrm{m}$ reaches within the 500-m experimental reach by adding a conservative tracer $(\mathrm{NaCl})$ to the stream and measuring conductivity $100 \mathrm{~m}$ downstream as the pulse passed (Webster and Valett 2006). We calculated discharge based on the average water velocity and stream profile area of the 100-m reach. We used temperature and light loggers (HOBO Pendant ${ }^{\circledR}$; Onset, Bourne, Massachusetts) to measure temperature at the middle of the reach every $10 \mathrm{~min}$. We used a geographic information system (GIS; ArcGIS, version 10.0; Environmental Research Systems Institute, Redlands, California) to estimate land use in a 50-m-wide buffer along all up-stream reaches (GIS layers; 'AIS_landuse' and 'Catchment' from the national catchment database; Aarhus University). We categorized land uses as agriculture, forest, fresh water, open, urban areas, and unknown.

We collected water samples twice (once before and once after the metabolism measurements) during a 1.5-mo period at base flow. We filtered some samples with glassfiber filters (Whatman ${ }^{\circledR}$; Buckinghamshire, UK) and stored all samples on ice until returning to the laboratory, where they were frozen. We analyzed filtered samples for inorganic nutrient concentrations $\left(\mathrm{NO}_{3}{ }^{-}, \mathrm{NH}_{4}{ }^{+}\right.$, soluble reactive $\mathrm{P}$ [SRP]) with a flow-injection analyzer (Lachat Instruments, Loveland, Colorado). We analyzed unfiltered samples for total N (TN) with a TOC-VCPH (Shimadzu, Kyoto, Japan) 
and total P (TP) with ammonium molybdate following a persulfate digestion. We measured water alkalinity by endpoint titration with $0.05 \mathrm{M} \mathrm{HCl}$.

\section{Habitat metabolism}

We measured habitat metabolism at each experimental reach in habitat types covering $>10 \%$ of the stream bed. We conducted measurements only on sunny days. At Linå, we conducted all habitat measurements within $16 \mathrm{~d}$ in late July-early August. At Skader, we conducted all habitat measurements within $6 \mathrm{~d}$ at the end of August. We conducted 39 habitat measurements, distributed among 4 habitat types: stone, gravel, sand, and macrophytes. At Linå, we measured habitat metabolism on stone $(n=8)$, gravel $(n=4)$, sand $(n=10)$, and macrophytes $(n=5)$. At Skader, we measured habitat metabolism only on stone $(n=4)$ and sand $(n=8)$ because macrophyte and gravel habitats either were not present or had limited occurrence.

We conducted the macrophyte habitat measurements at Linå in Ranunculus aquatilis L. beds because this was the predominant species present. Contributors to metabolism in the macrophyte habitat consisted of the macrophytes themselves, the epiphytic biofilm, and $\mathrm{O}_{2}$ that diffused from the water into the upper sediment beneath the macrophytes because of low $\mathrm{O}_{2}$ concentrations in the sediment. The deep sediment under the sand, gravel, and macrophytes was fine sand, which enclosed the cylinder tightly. Therefore, we expected that any exchange of water between chamber and hyporheic water would be insignificant. We also measured metabolism on artificial plants colonized by epiphytes at Linå $(n=6)$.

We measured habitat metabolism in sand and gravel in hemispheric Plexiglas ${ }^{\circledR}$ domes $($ diameter $=29 \mathrm{~cm}$, total height $=25 \mathrm{~cm}$, maximum volume $=13.7 \mathrm{~L})$ mounted with a circulation pump and an $\mathrm{O}_{2}$ probe (ProOdo; Yellow Springs Instruments, Yellow Springs, Ohio) that logged DO $\left(\mathrm{mg} \mathrm{O}_{2} / \mathrm{L}\right), \mathrm{O}_{2}$ saturation (DO\%), and temperature $\left({ }^{\circ} \mathrm{C}\right)$ every $10 \mathrm{~min}$ (Fellows et al. 2006, 2009). We embedded the dome $\sim 10 \mathrm{~cm}$ into the substrate to prevent or reduce water exchange through the hyporheic zone. To calculate the exact water volume inside the dome we removed the $\mathrm{O}_{2}$ probe and inserted a ruler. We measured the height from the streambed to the top of the dome after each habitat measurement and before moving the dome to another habitat. We measured metabolism in stone habitats in a closed dome because it was impossible to embed the dome into the stone substrate. We collected stones corresponding to the area of the bottom of the dome and placed them on a Plexiglas bottom before closing the dome and sealing it with sticky tack to prevent exchange of water or gasses between the dome and the surrounding waters. We left the domes totally submerged in the stream habitats for 24 to $30 \mathrm{~h}$ to calculate the metabolism during a whole day and to avoid nutrient limitation caused by cham- ber effects. The domes were surrounded by stream water, so the temperature did not differ between the habitat and the surroundings.

We collected substrate samples from all sand and gravel habitats to estimate autotrophic biomass and organic matter content. In sand habitats, we collected 3 samples with a tipless syringe (area $[\mathrm{A}]=6.6 \mathrm{~cm}^{2}$ ), whereas in gravel habitats, we collected 3 samples with a pipe $\left(A=22.7 \mathrm{~cm}^{2}\right)$. In stone habitats, we collected samples for measurement of autotrophic biomass by scraping biofilm from 3 stones $\left(\mathrm{A}=6.6 \mathrm{~cm}^{2} /\right.$ sample). We extracted chlorophyll $a$ (chl $a$; g chl $a / \mathrm{m}^{2}$ ) in $90 \%$ ethanol and measured concentrations with a spectrophotometer (UV-1700, UV-visible spectrophotometer; Shimadzu, Suzhou, China). We calculated organic matter in the sediment from the ash-free dry mass (AFDM) measured after dried samples were weighed, combusted at $550^{\circ} \mathrm{C}$ for $24 \mathrm{~h}$, and reweighed. We then calculated AFDM as \% organic matter in the sediment.

In macrophyte habitat, we measured metabolism in Plexiglas cylinders $\left(\mathrm{A}=102.1 \mathrm{~cm}^{2}\right.$, maximum volume $\left.=4.96 \mathrm{~L}\right)$. We placed the cylinder on top of the macrophyte bed, pushed it down through the macrophyte bed, and embedded it $\sim 10 \mathrm{~cm}$ into the sediment. This method enabled us to measure metabolism in a natural macrophyte bed and to include the upper sediment and the effect of shading from the surrounding macrophyte bed. We mounted the cylinders with a circulation pump and an $\mathrm{O}_{2}$ probe, closed them with a Plexiglas lid at the water surface, and sealed them with sticky tack to prevent gas exchange with the atmosphere. We left the cylinders in place for $\geq 2 \mathrm{~h}$ during midday and measured temperature and DO every $10 \mathrm{~min}$ with ProOdo probes. After the 2-h light incubation, we placed a dark cylinder around the Plexiglas cylinder so we could measure respiration rates in the dark. We waited $1 \mathrm{~h}$ after covering the cylinders so the autotrophs could adjust to the change from light to dark, after which we measured temperature and DO every $10 \mathrm{~min}$ for $\geq 2 \mathrm{~h}$. Next, we measured the distance from the stream bed to the water level in the cylinder to calculate the exact water volume. We collected all macrophytes in the cylinder, estimated the surface area of the macrophytes with the software AnalyzingDigital Images (version 2.0; MVH Image, Amherst, Massachusetts), and estimated their biomass after drying at $60^{\circ} \mathrm{C}$ for $\geq 48 \mathrm{~h}$. The surface area ranged from 24.3 to $434.4 \mathrm{~cm}^{2}$.

We measured epiphytic biofilm metabolism with biofilm established on artificial plants as a way to separate epiphytic biofilm metabolism from macrophyte metabolism in the macrophyte habitat. In total, we conducted 6 epiphytic biofilm metabolism measurements at Linå. We glued the artificial plants to a Plexiglas plate and placed the plates in the stream for $\geq 4$ wk before measurements to allow the biofilm to become established on the plants. We used 3 types of artificial plant: 1 with strap-like leaves resembling Sparganium spp. and the other 2 with dissected leaves resembling the submerged species Ranunculus spp. 
and Myriophyllum spp. All of these species are common in many temperate lowland streams. After $\geq 4 \mathrm{wk}$, we attached a cylinder similar to the one used for measurement of macrophyte metabolism to the plate with the artificial plant and measured metabolism as described above for macrophytes. At the end of the incubation, we recorded water depth in the cylinder to calculate the exact water volume and brought the artificial plants to the laboratory where we gently scrubbed the biofilm from the artificial plant and measured chl $a$ after filtering the slurry onto GF/C glass-fiber filters and extracting in ethanol. We scaled chl $a$ to $\mathrm{g} / \mathrm{m}^{2}$ plant by estimating the surface area of the artificial plants with the software AnalyzingDigitalImages. The surface area of the 3 types of artificial plants ranged from 154.4 to $429.5 \mathrm{~cm}^{2}$. We calculated epiphytic biofilm production as $\mathrm{g} \mathrm{O}_{2} \mathrm{~m}^{-2}$ plant surface $\mathrm{d}^{-1}$ using the increase or decrease in DO under light or dark conditions, respectively, and the area of the artificial plants.

At Linå, we recorded surface irradiance every $10 \mathrm{~min}$ during light and dark metabolism measurements with a temperature and light logger (HOBO, UA-002-64), and at Skader we recorded surface irradiance every $5 \mathrm{~min}$ with a light logger (LI 190SA; Li-COR, Lincoln, Nebraska). We calculated average photosynthetically active radiation (PAR) per measurement of dome/cylinder for the period when DO was being measured in the habitat.

We calculated GPP in the domes and cylinders based on 2 to $3 \mathrm{~h}$ of DO production measurements under light conditions to ensure that it reflected the maximum production rate. Estimates of CR of the organisms in the habitat were based on 2 to $3 \mathrm{~h}$ of measurements under dark conditions. Only CR measurements with DO concentrations $>3 \mathrm{mg} \mathrm{O}_{2} / \mathrm{L}$ were included to prevent inclusion of hypoxia effects during the measurements. Furthermore, to ensure that any change in metabolism was not caused by short-term effects of cloud shading, DO had to be linearly related to time $\left(r^{2}>0.85\right)$. We multiplied metabolic values $\left(\mathrm{g} \mathrm{O}_{2} \mathrm{~L}^{-1} \mathrm{~h}^{-1}\right)$ by water volume $(\mathrm{L})$ in the dome/ cylinder and divided by dome/cylinder bottom area $\left(\mathrm{m}^{2}\right)$ to obtain $\mathrm{g} \mathrm{O}_{2} \mathrm{~m}^{-2} \mathrm{~h}^{-1}$. Next, we calculated metabolic metrics (CR and NEP) for the biotic community in the domes. We calculated NEP as the rate of increase in DO in the dome/cylinder and scaled it to daily NEP rates by multiplying by the number of daily light hours. We calculated CR from the rate of decrease in DO during dark or night conditions and multiplied measurements by $24 \mathrm{~h}$ to obtain daily CR rate. The sum of NEP and CR for the photic period was GPP, and we calculated the ratio of production/respiration $(\mathrm{P} / \mathrm{R})$ for each habitat measurement as GPP/CR. Instead of using $P / R=1$ as the point at which the stream shifts between autotrophy and heterotrophy, we used the $0.63 \times$ GPP line presented by Hall and Beaulieu (2013). They compared the fraction from different streams worldwide and found that autotrophic ER constitutes $63 \%$ of GPP, whereas the rest is from the heterotro- phic organisms. Hereafter, we refer to this line as the 0.63GPP line.

We scaled habitat metabolism to estimate habitatweighted reach-scale net ecosystem production $\left(\mathrm{NEP}_{\mathrm{HAB}}\right.$ ), ecosystem respiration $\left(\mathrm{ER}_{\mathrm{HAB}}\right)$, and gross primary production $\left(\mathrm{GPP}_{\mathrm{HAB}}\right)$ by multiplying each habitat cover (\%) by the respective habitat metabolism $\left(\mathrm{g} \mathrm{O}_{2} \mathrm{~m}^{-2} \mathrm{~d}^{-1}\right)$. We summed the contribution from all habitats to obtain habitat-weighted reach-scale metabolism.

\section{Planktonic metabolism}

To quantify the metabolic contribution from the planktonic algae in the domes and cylinders, we incubated stream water in 3 light and 3 dark $200-\mathrm{mL}$ glass bottles for $3 \mathrm{~h}$ in the middle of the water column in the stream. We measured temperature and DO before and after incubation. We measured $\mathrm{P}$ and $\mathrm{R}$ as the rate of change in water $\mathrm{O}_{2}$ concentration from the start to end of the experiment (as described above for the domes/cylinders).

\section{Reach-scale metabolism}

We measured reach-scale metabolism with the upstream-downstream 2-station DO-change technique described by Odum (1956) and modified by Marzolf et al. (1994, 1998) and Young et al. (1998). We used YSI 6600 V2-2 Multiparameter Water Quality Probes (Yellow Springs Instruments, Yellow Springs, Ohio) to measure DO (mg/L) and temperature $\left({ }^{\circ} \mathrm{C}\right)$ every $10 \mathrm{~min}$ for $24 \mathrm{~h}$ during the habitat measurements. We calibrated the probes at $100 \%$ saturation with calibration caps before deploying them in the stream and corrected for drift in DO by intercalibrating the probes in the stream before and after measurements for $\geq 1 / 2 \mathrm{~h}$. We assumed the drift was linear over time and adjusted for differences among probes accordingly. At Linå, we measured surface irradiance with a temperature and light logger (HOBO, UA-002-64) every 10 min during metabolism measurement, and at Skader, we measured surface irradiance every $5 \mathrm{~min}$ with a LI 190SA meter. We calculated average PAR per day of metabolism measurement.

Reach-scale metabolic values obtained from openwater measurements are given as net ecosystem production $\left(\mathrm{NEP}_{\mathrm{RE}}\right)$ and ecosystem respiration $\left(\mathrm{ER}_{\mathrm{RE}}\right)$. The reach-scale metabolic metrics, $\mathrm{NEP}_{\mathrm{RE}}$ and $\mathrm{ER}_{\mathrm{RE}}$, differ from habitatweighted $\mathrm{NEP}_{\mathrm{HAB}}$ and $\mathrm{ER}_{\mathrm{HAB}}$ because they are based on changes in DO in open-water measurements across the whole reach rather than on measurements scaled up from NEP and CR in the domes. We measured $\mathrm{NEP}_{\mathrm{RE}}$ as the sum of the change in DO adjusted for temperature and reaeration according to Bott (2006) from $1 \mathrm{~h}$ after sunrise to $1 \mathrm{~h}$ before sunset (according to timeanddate.com). We calculated $E R_{R E}$ as the nighttime change in DO concentration caused by DO consumed, DO deficit, and reaeration from 0000 to $0300 \mathrm{~h}$, assuming constant rates throughout the day, and multiplied by 24 to get the daily rate. We calcu- 
lated $\mathrm{GPP}_{\mathrm{RE}}$ as the sum of $\mathrm{DO}$ produced in the photic period (sum of $\mathrm{NEP}_{\mathrm{RE}}$ during the photic period) plus DO consumed during the photic period calculated from nighttime respiration ( $E R_{R E}$ from night multiplied by photic hours). The reaches were too long to allow measurement of metabolism along the whole reach, so we separated them into 2 parts and averaged the metabolism per stream per day.

At Skader, we measured reaeration with propane release and salt as a conservative tracer (Marzolf et al. 1994). At Linå, propane measurement was not possible because the stream flooded immediately after metabolism measurements were made and before the planned propane release, so we estimated a reaeration coefficient, $k_{2}$, from an empirical model, the Surface Renewal Model (SRM) (Owens et al. 1964, Owens 1974) cited by Hauer and Lamberti (2006). We compared the measured values from the propane release in Skader with calculated values from the SRM, and the variability between the 2 methods was low (trace method: $k=0.014 / \mathrm{min}$ and $0.007 / \mathrm{min}$ for the 2 reaches; SRM model: $k=0.010 / \mathrm{min}$ and $0.007 / \mathrm{min}$ ), so we decided to use this model for Linå because the streams are physically comparable. We also tried other empirical methods from the literature (Aristegi et al. 2009), but none of these showed a reaeration coefficient as similar to the one calculated from the tracer. We could not use night time regression because the change in $\mathrm{O}_{2}$ during night was not $>1 \mathrm{mg} / \mathrm{L}$ during winter (Thyssen et al. (1987).

\section{Literature study}

We conducted a literature search on stream habitat metabolism to compare our habitat metabolism with other measurements. Measurements had been obtained by different methods, but all the studies included were conducted during summer. We obtained 73 comparable measurements from 11 studies on stream habitat metabolism and autotrophic biomass from the literature.

To compare the studies, we converted the metabolism ( $\mathrm{g} \mathrm{C} \mathrm{m}^{-2} \mathrm{~d}^{-1}$ ) estimates by Minshall et al. (1992), Fellows et al. (2006), and Reid et al. (2006) to $\mathrm{g} \mathrm{O}_{2} \mathrm{~m}^{-2} \mathrm{~d}^{-1}$ by dividing by $0.375 \mathrm{~g} \mathrm{C} / \mathrm{g} \mathrm{O}_{2}$ (following Lampert 1984 and Bender et al. 1987). We did not include studies in which metabolic rates were measured on an hourly basis $\left(\mathrm{g} \mathrm{O}_{2}\right.$ $\mathrm{m}^{-2} \mathrm{~h}^{-1}$ ) because day length was not given, so we could not convert hourly rates to $\mathrm{g} \mathrm{O}_{2} \mathrm{~m}^{-2} \mathrm{~d}^{-1}$ except for Biggs et al. (1999) and Fellows et al. (2001), for which we multiplied respiration rates by $24 \mathrm{~h}$ to obtain daily rates.

\section{Statistics}

We used 1-way analysis of variance (ANOVA) and a multiple range test (Least Significant Difference [LSD]) to test for differences in metabolic rates among habitats. Before applying the ANOVA, we tested for homogeneity of variance in all data. To identify which variables con- trolled habitat metabolism, we applied a General Linear Model (GLM). Variables included in the GLM were autotrophic biomass, stream (Linå, Skader), habitat type, water quality, \% cover of agricultural land use in a 50-mwide buffer zone up-stream of the study reach, maximum temperature inside the dome/cylinder, water velocity in the stream reach, water depth and transect width where the dome/cylinder was placed, sediment organic matter (\%) inside the dome, and average PAR measured during community production in the domes. We used comparison of regression lines to compare the slopes of lines. When necessary, data were $\log (x)$-transformed to obtain homoscedasticity.

\section{RESULTS}

\section{Physical and chemical characteristics}

Nutrient concentrations were 2 to $5 \times$ higher in Skader than in Linå except for $\mathrm{NH}_{4}{ }^{+}$, for which concentrations were similar in the 2 streams (Table 1). Average temperature was comparable in the 2 streams. Lina had twice the discharge of Skader, and both catchments were dominated by agricultural land use (Table 1 ).

\section{Habitat metabolism}

NEP, CR, and GPP estimated from change in DO in the dome/cylinder differed among the 4 habitat types and between Linå and Skader and were positively correlated

Table 1. Mean $( \pm \mathrm{SD}, n=2)$ physicochemical measurements for Linå and Skader. Temperature is mean $( \pm$ SD) from the middle of June to the middle of October, and catchment land use is \% total catchment area. * indicates significant differences between streams $(p<0.05)$.

\begin{tabular}{lcc}
\hline & \multicolumn{2}{c}{ Stream } \\
\cline { 2 - 3 } \multicolumn{1}{c}{ Variable } & Linå & Skader \\
\hline Alkalinity $(\mathrm{meq} / \mathrm{L})$ & 1.59 & 2.74 \\
$\mathrm{NH}_{4}{ }^{-}(\mathrm{mg} / \mathrm{L})$ & 0.05 & 0.04 \\
$\mathrm{NO}_{3}{ }^{-}(\mathrm{mg} / \mathrm{L})$ & 2.37 & 5.60 \\
$\mathrm{Total}^{3-}(\mathrm{mg} / \mathrm{L})$ & 2.62 & 5.37 \\
$\mathrm{PO}_{4}{ }^{--}(\mathrm{mg} / \mathrm{L})$ & 0.01 & 0.05 \\
$\mathrm{Total}^{\mathrm{P}}(\mathrm{mg} / \mathrm{L})$ & 0.08 & 0.14 \\
Temperature $\left({ }^{\circ} \mathrm{C}\right)$ & $13.93 \pm 1.18$ & $13.86 \pm 2.35$ \\
Discharge $\left(\mathrm{m}^{3} / \mathrm{s}\right)$ & 0.17 & 0.08 \\
Stream width $(\mathrm{m})$ & $2.87 \pm 0.67$ & $3.25 \pm 1.09^{*}$ \\
Stream depth $(\mathrm{m})$ & $0.34 \pm 0.22^{*}$ & $0.30 \pm 0.14$ \\
\% agriculture & 50 & 66 \\
\% forest & 7 & 11 \\
\% open nature & 2 & 10 \\
\% urban & 3 & 6 \\
\% freshwater areas & 38 & 5 \\
\hline
\end{tabular}


Table 2. Results of a General Linear Model for the effects of habitat variables on net ecosystem production (NEP; $\mathrm{g} \mathrm{O}_{2} \mathrm{~m}^{-2} \mathrm{~d}^{-1}$ ), community respiration $\left(\mathrm{CR} ; \mathrm{g} \mathrm{O}_{2} \mathrm{~m}^{-2} \mathrm{~d}^{-1}\right.$ ), and gross primary production (GPP; $\mathrm{g} \mathrm{O}_{2} \mathrm{~m}^{-2} \mathrm{~d}^{-1}$ ) for all habitat measurements. Only variables with significant effects are included. Habitat includes stone, gravel, sand, and macrophyte. Biomass $=$ autotrophic biomass in the different habitat types and is directly related to metabolism.

\begin{tabular}{|c|c|c|c|c|c|c|}
\hline \multirow[b]{2}{*}{ Variable } & \multicolumn{2}{|c|}{ NEP } & \multicolumn{2}{|c|}{$\mathrm{CR}$} & \multicolumn{2}{|c|}{ GPP } \\
\hline & $F$ & $p$ & $F$ & $p$ & $F$ & $p$ \\
\hline Habitat & 18.72 & $<0.0001$ & 47.28 & $<0.0001$ & 41.15 & $<0.0001$ \\
\hline Stream & 48.16 & $<0.0001$ & 39.35 & $<0.0001$ & 73.04 & $<0.0001$ \\
\hline Log(biomass) & 7.54 & 0.0097 & 14.70 & 0.0005 & 13.93 & 0.0007 \\
\hline
\end{tabular}

with the autotrophic biomass in the habitat (GLM, $r^{2}=$ 0.77 for NEP, $r^{2}=0.86$ for GPP and CR; Table 2). Macrophyte habitats had significantly higher CR and GPP than stone, gravel, or sand habitats, and sand habitats had higher CR and GPP than stone habitats (Table 3). NEP did not vary among habitat types. All habitats had $P / R>0.63$. Macrophyte habitats had the lowest ratio, but only $\mathrm{P} / \mathrm{R}$ for gravel was significantly higher than for macrophytes (Table 3). Epiphytic biofilm contributed $28 \%$ to total macrophyte habitat NEP, $20 \%$ to macrophyte habitat CR, and $24 \%$ to macrophyte habitat GPP on a plant-area basis (Table 3), but P/R did not differ significantly between epi- phytes and macrophytes. Planktonic algae did not contribute to habitat metabolism because DO did not differ between bottles incubated under light and dark conditions (data not shown).

In general, GPP and CR were higher at Linå than at Skader across all habitats, mainly because of the higher activity in sand habitats and the high GPP and CR in macrophyte habitat, which was present only in Linå (Fig. 1A, B). CR and GPP and autotroph biomass were positively related across all habitats at Skader and Linå (CR: $r^{2}=$ $0.81, p<0.0001$; GPP: $\left.r^{2}=0.78, p<0.0001\right)$, and the positive relationship was supported more generally when measurements from the literature were considered together with our measurements (Fig. 1A, B). The data obtained from measurements in Linå and Skader included the full range of biomasses reported in the literature. The 4 highest biomass measurements in our study originated from macrophyte habitats (circle in Fig. 1A, B) and the lowest biomass measurements originated from stone habitats.

\section{Habitat-weighted reach-scale metabolism}

At both streams, $\mathrm{NEP}_{\mathrm{RE}}$ was $\sim 3 \times$ higher than $\mathrm{NEP}_{\mathrm{HAB}}$, and $\mathrm{ER}_{\mathrm{RE}}$ was 3 to $8 \times$ higher than $\mathrm{ER}_{\mathrm{HAB}}$ (Table 4 ). ER and GPP were higher at Linå than Skader regardless of the method used.

Habitat cover at Linå was $14 \%$ macrophytes ( $R$. aquatilis), $41 \%$ sand, $22 \%$ gravel, and $23 \%$ stone, whereas the habitat cover at Skader was $68 \%$ sand, $8 \%$ gravel, and $24 \%$

Table 3. Mean $( \pm \mathrm{SD})$ net ecosystem production (NEP; $\left.\mathrm{g} \mathrm{O}_{2} \mathrm{~m}^{-2} \mathrm{~d}^{-1}\right)$, community respiration $\left(\mathrm{CR} ; \mathrm{g} \mathrm{O}_{2} \mathrm{~m}^{-2} \mathrm{~d}^{-1}\right)$, gross primary production (GPP; $\mathrm{g} \mathrm{O}_{2} \mathrm{~m}^{-2} \mathrm{~d}^{-1}$ ), and production/respiration (P/R) for the different habitat types ( $n=12$ for stone, $n=4$ for gravel, $n=18$ for sand, $n=5$ for macrophytes) and areal NEP $\left(\mathrm{g} \mathrm{O}_{2} \mathrm{~m}^{-2}\right.$ plant $\left.\mathrm{d}^{-1}\right)$, CR $\left(\mathrm{g} \mathrm{O}_{2} \mathrm{~m}^{-2}\right.$ plant d $\left.{ }^{-1}\right)$, GPP $\left(\mathrm{g} \mathrm{O}_{2} \mathrm{~m}^{-2}\right.$ plant d $\left.\mathrm{d}^{-1}\right)$, and $\mathrm{P} / \mathrm{R}$ for macrophytes and epiphytic biofilm $(n=5$ for macrophytes and $n=6$ for epiphytic biofilm) for measurements from both streams. The chamber type used for each measurement is indicated, and closed/open refers to whether the chamber included a bottom (closed) or not (open). Macrophyte habitats are beds of Ranunculus aquatilis. Values with the same letters are not significantly different between habitat types or $R$. aquatilis and epiphytic biofilm $(p<0.05)$. Epiphytic biofilm is included in the $R$. aquatilis habitat.

\begin{tabular}{|c|c|c|c|c|c|}
\hline \multirow[b]{2}{*}{ Variable } & \multicolumn{5}{|c|}{ Habitat or autotroph type } \\
\hline & $\begin{array}{c}\text { Stone } \\
\text { Dome, closed }\end{array}$ & $\begin{array}{c}\text { Gravel } \\
\text { Dome, open }\end{array}$ & $\begin{array}{c}\text { Sand } \\
\text { Dome, open }\end{array}$ & $\begin{array}{c}\text { Macrophyte } \\
\text { Cylinder, open }\end{array}$ & $\begin{array}{l}\text { Epiphytic biofilm } \\
\text { Cylinder, closed }\end{array}$ \\
\hline \multicolumn{6}{|l|}{ Daily rate } \\
\hline $\operatorname{NEP}\left(\mathrm{g} \mathrm{O}_{2} \mathrm{~m}^{-2} \mathrm{~d}^{-1}\right)$ & $0.10^{\mathrm{a}} \pm 0.33$ & $0.24^{\mathrm{a}} \pm 0.27$ & $0.35^{\mathrm{a}} \pm 0.53$ & $-1.54^{\mathrm{a}} \pm 1.73$ & \\
\hline $\mathrm{CR}\left(\mathrm{g} \mathrm{O}_{2} \mathrm{~m}^{-2} \mathrm{~d}^{-1}\right)$ & $0.84^{\mathrm{a}} \pm 0.44$ & $0.71^{\mathrm{ab}} \pm 0.31$ & $1.39^{\mathrm{b}} \pm 0.78$ & $11.85^{\mathrm{c}} \pm 6.08$ & \\
\hline $\operatorname{GPP}\left(\mathrm{g} \mathrm{O}_{2} \mathrm{~m}^{-2} \mathrm{~d}^{-1}\right)$ & $0.94^{\mathrm{a}} \pm 0.45$ & $0.94^{\mathrm{ab}} \pm 0.36$ & $1.75^{\mathrm{b}} \pm 1.05$ & $10.31^{\mathrm{c}} \pm 5.43$ & \\
\hline $\mathrm{P} / \mathrm{R}$ & $1.16^{\mathrm{ab}} \pm 0.38$ & $1.43^{\mathrm{b}} \pm 0.45$ & $1.27^{\mathrm{ab}} \pm 0.41$ & $0.89^{\mathrm{a}} \pm 0.15$ & \\
\hline \multicolumn{6}{|l|}{ Areal rate } \\
\hline $\operatorname{NEP}\left(\mathrm{g} \mathrm{O}_{2} \mathrm{~m}^{-2}\right.$ plant $\left.\mathrm{d}^{-1}\right)$ & & & & $3.08^{b} \pm 2.60$ & $0.85 \pm 0.39$ \\
\hline $\mathrm{CR}\left(\mathrm{g} \mathrm{O}_{2} \mathrm{~m}^{-2}\right.$ plant $\left.\mathrm{d}^{-1}\right)$ & & & & $6.28^{\mathrm{b}} \pm 3.97$ & $1.24^{\mathrm{a}} \pm 0.43$ \\
\hline GPP $\left(\mathrm{g} \mathrm{O}_{2} \mathrm{~m}^{-2}\right.$ plant $\left.\mathrm{d}^{-1}\right)$ & & & & $5.79^{\mathrm{b}} \pm 4.17$ & $1.39^{\mathrm{a}} \pm 0.46$ \\
\hline $\mathrm{P} / \mathrm{R}$ & & & & $0.89^{\mathrm{a}} \pm 0.15$ & $1.17^{\mathrm{a}} \pm 0.34$ \\
\hline
\end{tabular}




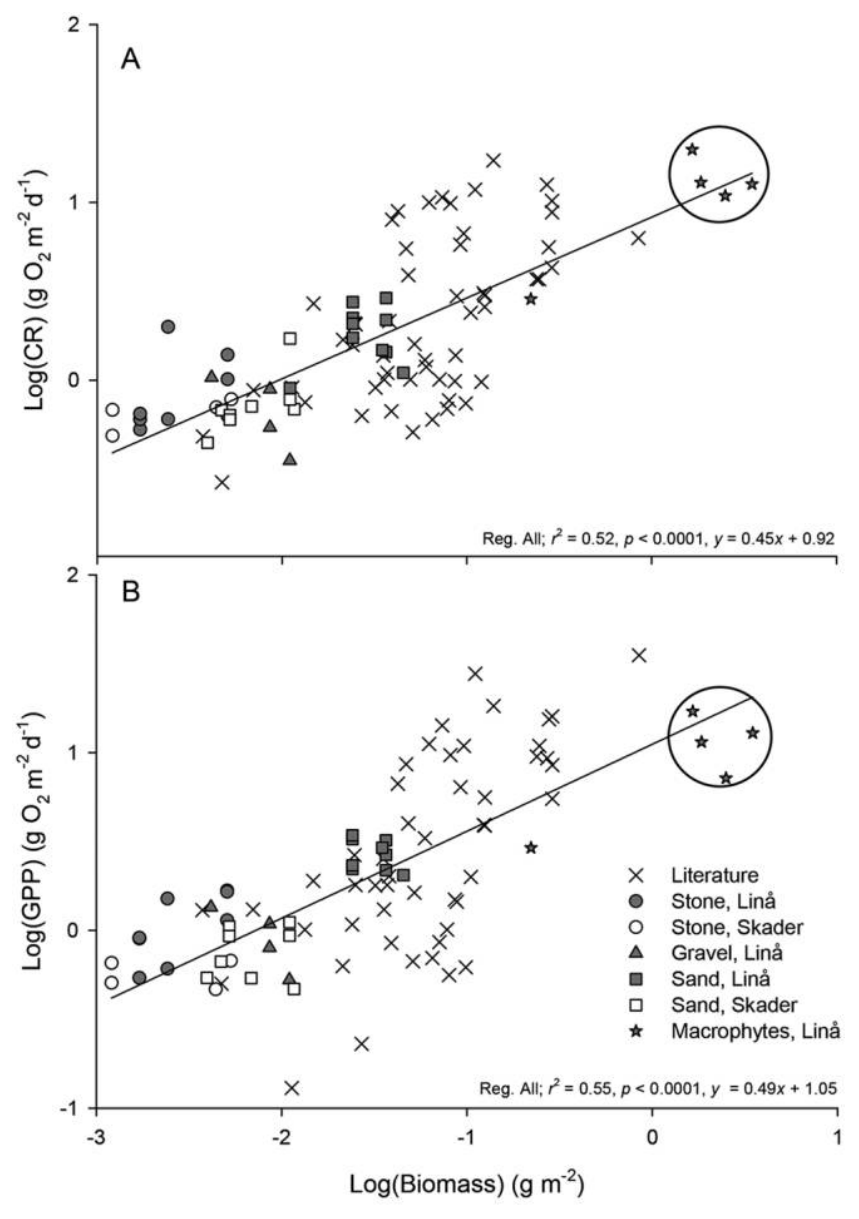

Figure 1. Relationship between community respiration (CR) (A) and gross primary production (GPP) (B) and autotrophic biomass from the literature (Table S1) and this study. Data from Linå and Skader are reported for each habitat type. Reg. = regression.

stone (Fig. 2). At Linå, habitat-weighted whole-reach metabolism showed that the $14 \%$ of the reach covered by macrophytes contributed disproportionally more to metabolism than other habitats. Macrophyte habitat contributed 41,60 , and $50 \%$ to $\mathrm{NEP}_{\mathrm{HAB}}, \mathrm{ER}_{\mathrm{HAB}}$, and $\mathrm{GPP}_{\mathrm{HAB}}$, respectively, whereas sand habitat in Linå contributed 43, 28, and $36 \%$, respectively. At Skader, the $68 \%$ of the reach covered by sand contributed 78,77 , and $79 \%$ to $\mathrm{NEP}_{\mathrm{HAB}}$, $\mathrm{ER}_{\mathrm{HAB}}$, and $\mathrm{GPP}_{\mathrm{HAB}}$, respectively, whereas the $24 \%$ covered by stone contributed 22, 23, and $21 \%$, respectively.

Our measurements of habitat metabolism were within the range of other habitat metabolism measurements reported in the literature (Fig. 3). The distribution of different types of habitats was highly uneven among the 73 measurements reported in the literature. Most studies were conducted in gravel/cobble habitat (32 studies) or sand habitat (15 studies), and only 8 studies were conducted in stone habitat, 5 in macrophyte habitat, 1 in epi- pelon, and 3 in floating macroalgae. For 8 of the measurements reported in the literature, we used only values for respiration and biomass because we were unable to convert GPP rates into daily rates. GPP varied between 0.0 and $35.3 \mathrm{~g} \mathrm{O}_{2} \mathrm{~m}^{-2} \mathrm{~d}^{-1}$ and $\mathrm{CR}$ varied between 0.07 and $17.2 \mathrm{~g} \mathrm{O}_{2} \mathrm{~m}^{-2} \mathrm{~d}^{-1}$ (Table S1), but most habitats had GPP and CR between 0.5 and $4 \mathrm{~g} \mathrm{O}_{2} \mathrm{~m}^{-2} \mathrm{~d}^{-1}$. The highest values of GPP and CR in the literature $\left(>15 \mathrm{~g} \mathrm{O}_{2} \mathrm{~m}^{-2} \mathrm{~d}^{-1}\right)$ were for floating macroalgae (Acuña et al. 2011) and in a polluted stream affected by intensive managed tree plantations (Aristegi et al. 2010). The lowest CR values were measured by Biggs et al. (1999) on unstable substrate in streams with high water velocities. In general, stone, gravel, and sand habitats varied within the same range, and no habitat-specific patterns were found in their metabolism.

The regressions for CR vs GPP were significant with our data from Linå and our data pooled with the metabolic rates from the literature, despite the difference in autotrophic organisms among habitats (Fig. 3). The slopes of both regressions differed from the 0.63GPP line (All: $F=$ 24.04, $p<0.001$; Linå: $F=8.66, p=0.004)$. When we considered the data by habitat type, the slopes of the regressions for CR vs GPP differed from the 0.63GPP line in all habitats (stone: $F=129.09, p<0.001$; gravel: $F=$ 3.99, $p=0.049$; sand: $F=49.59, p=<0.001$; macrophytes: $F=7.59, p=0.008 ;$ Fig. $4 \mathrm{~A}-\mathrm{D})$.

\section{DISCUSSION \\ Habitat metabolism}

Metabolic rates were much higher in macrophyte than other habitats in streams, and the epiphytic biofilm contributed significantly to this metabolism. GPP and CR were 6 to $17 \times$ higher in $R$. aquatilis habitats than in stone, gravel, and sand habitats, with microalgae being the dominant primary producer. CR and GPP measurements in macrophyte

Table 4. Reach-scale net ecosystem production (NEP), ecosystem respiration (ER), gross primary production (GPP), and GPP/ER estimated based on habitat-weighted metabolism $\left(\mathrm{NEP}_{\mathrm{HAB}}, \mathrm{ER}_{\mathrm{HAB}}, \mathrm{GPP}_{\mathrm{HAB}}\right)$ and the 2-station method (NEP $\mathrm{RE}_{\mathrm{RE}}$, $\left.\mathrm{ER}_{\mathrm{RE}}, \mathrm{GPP}_{\mathrm{RE}}\right)$. Data on 2-station metabolism are averaged for 2 reaches in Linå and Skader. Numbers are means and do not necessarily sum up.

\begin{tabular}{|c|c|c|c|c|}
\hline \multirow[b]{2}{*}{ Variable } & \multicolumn{2}{|c|}{$\begin{array}{l}\text { Habitat- } \\
\text { weighted }\end{array}$} & \multicolumn{2}{|c|}{ 2-station } \\
\hline & Linå & Skader & Linå & Skader \\
\hline $\mathrm{NEP}_{\mathrm{HAB} / \mathrm{RE}}\left(\mathrm{g} \mathrm{O}_{2} \mathrm{~m}^{-2} \mathrm{~d}^{-1}\right)$ & 1.58 & 0.44 & -2.52 & -1.04 \\
\hline $\mathrm{ER}_{\mathrm{HAB} / \mathrm{RE}}\left(\mathrm{g} \mathrm{O}_{2} \mathrm{~m}^{-2} \mathrm{~d}^{-1}\right)$ & 2.76 & 0.69 & 8.72 & 5.48 \\
\hline $\operatorname{GPP}_{\mathrm{HAB} / \mathrm{RE}}\left(\mathrm{g} \mathrm{O}_{2} \mathrm{~m}^{-2} \mathrm{~d}^{-1}\right)$ & 2.88 & 0.67 & 2.57 & 1.71 \\
\hline $\mathrm{GPP} / \mathrm{ER}_{\mathrm{HAB} / \mathrm{RE}}$ & 1.04 & 0.97 & 0.45 & 0.36 \\
\hline
\end{tabular}




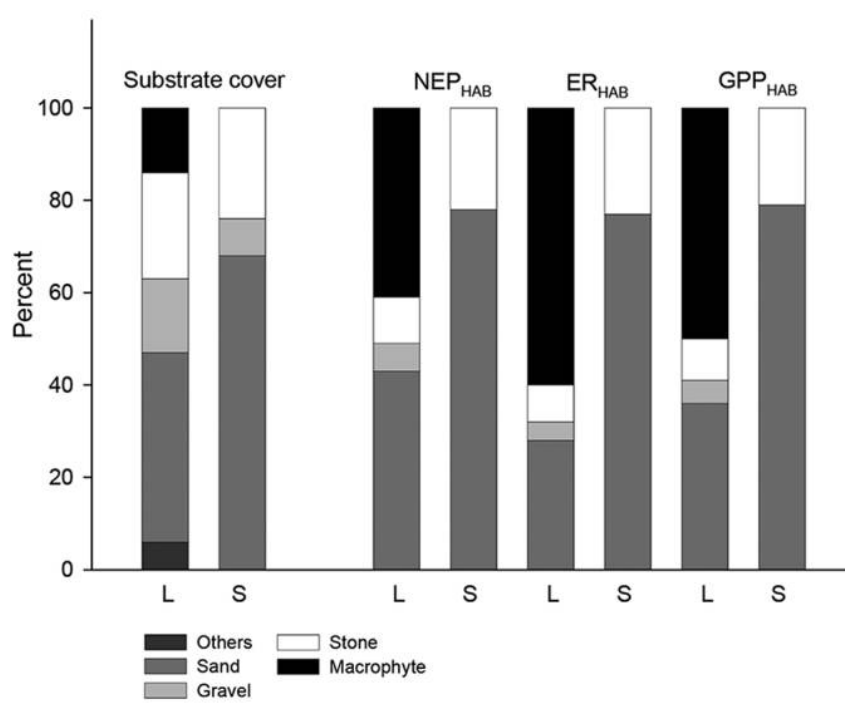

Figure 2. Percent substrate cover and \% contribution of sand, gravel, stone, macrophyte, and other habitats to reach-scale net ecosystem production $\left(\mathrm{NEP}_{\mathrm{HAB}}\right)$, ecosystem respiration $\left(\mathrm{ER}_{\mathrm{HAB}}\right)$, and gross primary production $\left(\mathrm{GPP}_{\mathrm{HAB}}\right)$ for Linå $(\mathrm{L})$ and Skader $(\mathrm{S})$.

habitats in our study (CR: 10.9-19.9 $\mathrm{g} \mathrm{O}_{2} \mathrm{~m}^{-2} \mathrm{~d}^{-1}$; GPP: 7.19-17.1 $\mathrm{g} \mathrm{O}_{2} \mathrm{~m}^{-2} \mathrm{~d}^{-1}$ ) and metabolic rates in cobble habitats dominated by filamentous green algae in Spanish streams (maximum $\mathrm{CR}=17 \mathrm{~g} \mathrm{O} \mathrm{m}^{-2} \mathrm{~d}^{-1}$; maximum $\mathrm{GPP}=35 \mathrm{~g} \mathrm{O}_{2} \mathrm{~m}^{-2} \mathrm{~d}^{-1}$; Aristegi et al. 2010) were among the highest values reported in the literature.

The epiphytic biofilm contributed, on average, 28, 20, and $24 \%$ to NEP, CR, and GPP, respectively. The high metabolic contribution from the biofilm emphasizes the importance of macrophytes as substrate for biofilm and, therefore, as a hotspot for microbial metabolism (Pomazkina et al. 2012, Tunca et al. 2014). The distribution of epiphytic biofilm differs within macrophyte beds, and the differences must be considered when scaling metabolic rates to the whole-ecosystem level. For example, biofilm can grow thick mats on macrophyte surfaces in summer, but its biomass is likely to vary within macrophyte beds because light may be limiting in the deeper areas, and differing water velocities within the bed can affect $\mathrm{CO}_{2}$ and nutrient uptake (Biggs et al. 2005). Our results were based on the assumption that biofilm was evenly distributed throughout the macrophyte beds. The beds were only $0.2 \mathrm{~m}$ deep, so light probably was not limited at that depth.

We also assumed that metabolic rates of biofilm would be similar on natural and artificial plants. However, natural and artificial plants could have affected biomass of the epiphytic biofilm differently. For example, artificial plants might affect water velocity in a way that differs from natural plants if they differ physically from natural plants (e.g., in surface area). Moreover, natural and artificial plants might differ chemically because some natural macrophytes release allelopathic chemicals that can inhibit the growth of other organisms. However, we expected these effects to be minimal and that biofilm would grow on almost everything. We also expected that once established, biofilm would grow in all 3 dimensions, regardless of the substrate being natural or artificial plants. However, more studies are needed to predict more precisely how biofilm may affect the habitat metabolism within macrophyte beds and whether plant surface area or allelopathic activity are key factors for colonization.

All 4 habitats had $P / R>0.63$, but macrophyte habitats had the lowest P/R (0.89). We expected NEP to be much higher on an areal basis in macrophyte than in nonmacrophyte habitat because of the high autotrophic biomass of the macrophyte habitats. However, CR rates were higher than GPP rates in macrophyte habitat. High CR probably reflects a combination of several factors. First, water velocity is lower in a macrophyte bed than in other stream habitats. Therefore, deposition of fine substrate and organic matter is high in macrophyte beds and leads to higher $\mathrm{O}_{2}$ consumption because of high breakdown rates (SandJensen 1998, Jones et al. 2011). Second, macrophytes must sustain large amounts of nonphotosynthetic tissue and transport ions over long distances. These processes require respiration by the plant.

Overall, CR was linked to GPP in the 4 habitat types, especially in gravel habitat. In all 4 habitat types, the slope of the relationship differed from the 0.63GPP line, but the slope was higher only in macrophyte habitat. This result indicates that the high $\mathrm{CR}$ in macrophyte habitats arose

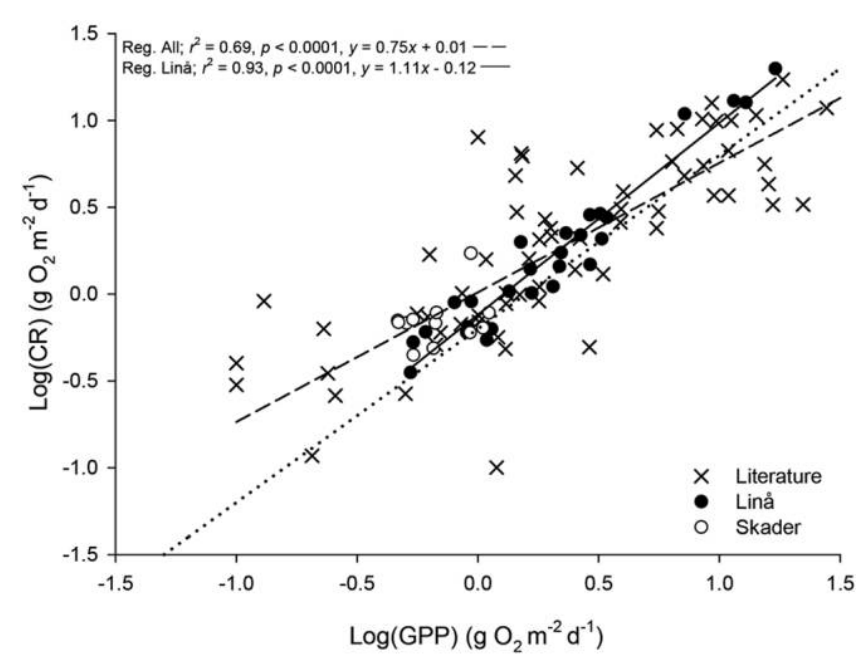

Figure 3. Relationship between community respiration (CR) and gross primary production (GPP) from Linå, Skader, and data from the literature (Table S1). Dotted line indicates the 0.63GPP relationship. The regression lines show the overall trends for all values (Linå, Skader, and literature data) and for Linå alone. Reg. = regression. 


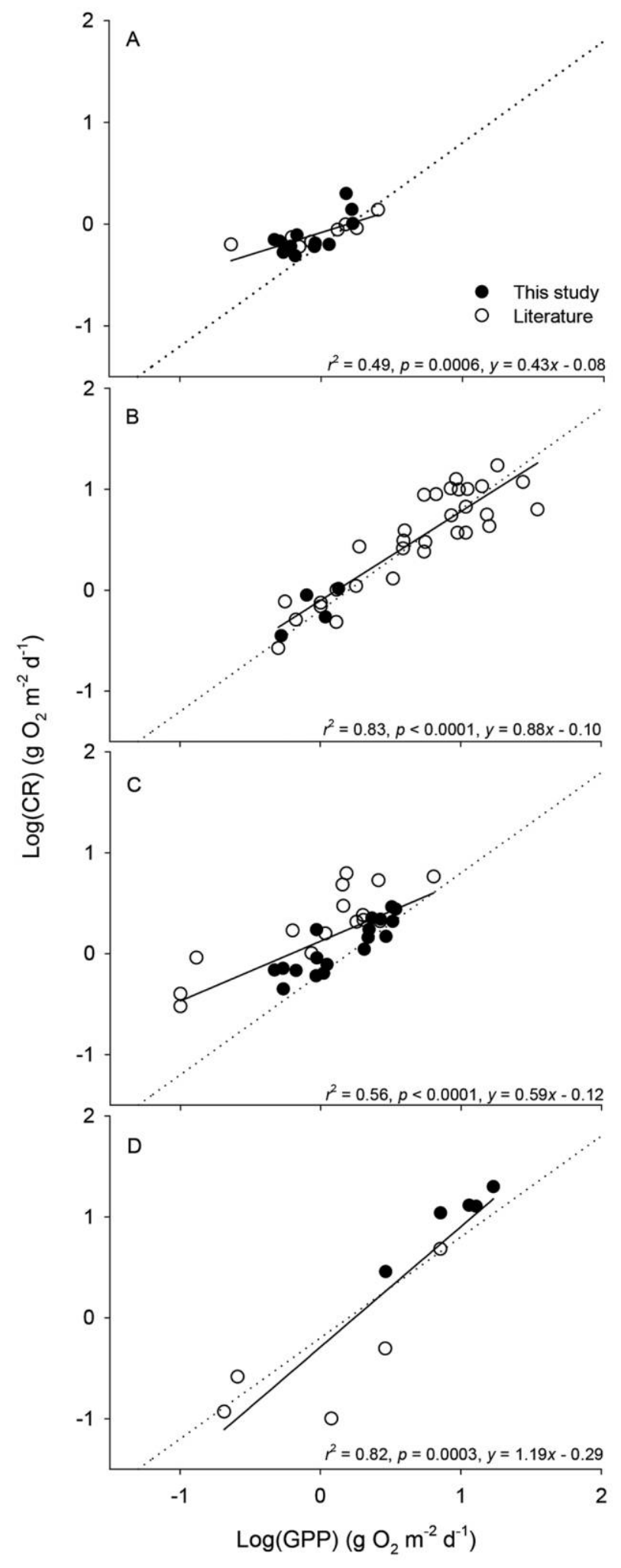

Figure 4. Relationship between community respiration (CR) and gross primary production (GPP) from stone (A), gravel (B), sand $(C)$, and macrophyte (D) habitat from this study and data from the literature (Table S1). Dotted line indicates 0.63GPP relationship. from the macrophytes themselves and from the sediment. The slope was lowest in stone habitats. This result could have been because of underestimation of $\mathrm{CR}$ in the closed chambers where the contribution from the surface and interstitial sediments was not estimated.

\section{Reach-scale metabolism}

Habitat-weighted estimation of reach-scale metabolism based on both habitat measurements and the reach-scale method showed that ER and GPP were higher at Linå, which had $14 \%$ cover of $R$. aquatilis, than at unvegetated Skader. At Lina, the $14 \%$ of the streambed covered by $R$. aquatilis contributed disproportionately to reach-scale $\mathrm{NEP}_{\mathrm{HAB}}(41 \%), \mathrm{ER}_{\mathrm{HAB}}(60 \%)$, and $\mathrm{GPP}_{\mathrm{HAB}}(50 \%)$, results that lend support to the suggestion that the difference in reach-scale metabolism between the 2 study streams was caused mainly by macrophyte cover. Nutrient concentration did not differ between the streams, and organic matter, light, and temperature were not among the best predictive variables in the GLM. Macrophyte beds may be hotspots of high metabolic activity by the macrophytes, their epiphytic biofilm, and the heterotrophic organisms in the upper layer of fine sediment in the macrophyte bed. Madsen et al. (1988) showed that reach-scale GPP and ER were reduced significantly after removal of macrophyte biomass via weed cutting, even though only half of the biomass was removed. Furthermore, in a manipulative study of macrophyte cover during growing season, O'Brien et al. (2014) found a positive relationship between GPP and macrophyte cover in 3 New Zealand lowland streams.

Estimates of metabolic rates differed between 2-station measurements and habitat-weighted measurements. $E R_{R E}$ was $3 \times$ higher than $\mathrm{ER}_{\mathrm{HAB}}$ in Linå and $8 \times$ higher in Skader. GPP values were more-or-less similar between methods at Linå, but GPP $\mathrm{RE}_{\mathrm{RE}}$ was $2.5 \times$ higher than $\mathrm{GPP}_{\mathrm{HAB}}$ at Skader. The higher $\mathrm{GPP}_{\mathrm{RE}}$ than $\mathrm{GPP}_{\mathrm{HAB}}$ and higher $\mathrm{ER}_{\mathrm{RE}}$ than $E R_{\mathrm{HAB}}$ at Skader may reflect our inability to fit the large stones in the reach into the chambers. Thus, we had to use smaller stones to measure metabolic rates in stone habitats. Biofilm mats can grow thicker on big than on small stones because big stones are more stable. Thus, GPP and ER may have been underestimated for $\mathrm{ER}_{\mathrm{HAB}}$ and $\mathrm{GPP}_{\mathrm{HAB}}$, respectively. Furthermore, the small stones used were from a riffle where biomass on stones could have been reduced because stones were continuously rotated and moved, processes that reduce the biomass. Moreover, a lower $\mathrm{ER}_{\mathrm{HAB}}$ than $E R_{R E}$ also might reflect that we did not measure the contribution from the upper sediments in the stone chambers and, therefore, underestimated $\mathrm{ER}_{\mathrm{HAB}}$. In addition, the lower habitat-weighted rates potentially may be ascribed to the fact that some habitats, such as leaf litter and other organic detritus that might contribute significantly to reachscale metabolism, were missing from the habitat-weighted 
metabolism (Hedin 1990, Fuss and Smock 1996, Houser et al. 2005). Amphibious plants growing at the margins of the streams also may have contributed to ER because they are rooted in the stream bottom. However, they contribute only negligibly, if at all, to in-stream DO production because the gas exchange occurs primarily over the leaves above the water surface.

\section{Conclusion}

Our results showed that macrophyte habitats had a significant and disproportionately higher contribution to stream metabolism than stone, gravel, and sand habitats in lowland streams. The high GPP in the macrophyte habitats was caused by the plant itself and its epiphytic biofilm, which constituted $24 \%$ of the GPP. The high CR in the macrophyte habitats was caused by macrophytes, epiphytic biofilm (20\%), and microbial heterotrophic processes in the upper sediment deposited in the macrophyte beds. Deposition and mineralization of fine organic matter in the stream reduce the transport of organic matter to downstream recipients, such as lakes and coastal waters. The higher metabolic rates in macrophyte than in other habitats could be explained largely by the higher autotrophic biomass/streambed area, a conclusion supported by a comparison of metabolic metrics from a wide range of stream types. Our study confirms that besides having an effect on the structural elements in streams, macrophytes contribute significantly to stream ecosystem function through metabolism.

\section{ACKNOWLEDGEMENTS}

The authors acknowledge the Carlsberg Foundation (TR), the Danish Natural Science Research Council (TR), the European Union $7^{\text {th }}$ Framework Project REFRESH under contract 244121 (ABP) and 'Managing aquatic ecosystems and water resources under multiple stress' (MARS) under contract 603378 (ABP) for financial support. We thank Søren E. Larsen for help with the statistical analyses and Søren B. Alnøe for technical support and data collection. Furthermore, we thank the editors and 2 anonymous referees for comments and improvements on the manuscript.

\section{LITERATURE CITED}

Acuña, V., C. Vilches, and A. Giorgi. 2011. As productive and slow as a stream can be-the metabolism of a Pampean stream. Journal of the North American Benthological Society 30:71-83.

Aristegi, L., O. Izagirre, and A. Elosegi. 2009. Comparison of several methods to calculate reaeration in streams, and their effects on estimation of metabolism. Hydrobiologia $635: 113-$ 124.
Aristegi, L., O. Izagirre, and A. Elosegi. 2010. Metabolism of Basque streams measured with incubation chambers. Limnetica 29:301-310.

Bender, M., K. Grande, K. Johnson, J. Marra, P. J. L. Williams, J. Sieburth, M. Pilson, C. Langdon, G. Hitchcock, J. Orchardo, C. Blunt, P. Donaghay, and K. Heinemann. 1987. A comparison of four methods for determining planktonic community production. Limnology and Oceanography 32: 1085-1098.

Bernot, M. J., D. J. Sobota, R. O. Hall, P. J. Mulholland, W. K. Dodds, J. R. Webster, J. L. Tank, L. R. Ashkenas, L. W. Cooper, C. N. Dahm, S. V. Gregory, N. B. Grimm, S. K. Hamilton, S. L. Johnson, W. H. McDowell, J. L. Meyer, B. Peterson, G. C. Poole, H. M. Valett, C. Arango, J. J. Beaulieu, A. J. Burgin, C. Crenshaw, A. M. Helton, L. Johnson, J. Merriam, B. R. Niederlehner, J. M. O’Brien, J. D. Potter, R. W. Sheibley, S. M. Thomas, and K. Y. M. Wilson. 2010. Interregional comparison of land-use effects on stream metabolism. Freshwater Biology 55:1874-1890.

Binzer, T., K. Sand-Jensen, and A. Middelboe. 2006. Community photosynthesis of aquatic macrophytes. Limnology and Oceanography 51:2722-2733.

Biggs, B. J. F., V. I. Nikora, and T. H. Snelder. 2005. Linking scales of flow variability to lotic ecosystem structure and function. River Research and Applications 21:283-298.

Biggs, B. J. F., R. A. Smith, and M. J. Duncan. 1999. Velocity and sediment disturbance of periphyton in headwater streams: biomass and metabolism. Journal of the North American Benthological Society 18:222-241.

Bott, T. L. 2006. Primary productivity and community respiration. Pages 663-690 in F. R. Hauer and G. A. Lamberti (editors). Methods in stream ecology. Academic Press, Amsterdam, The Netherlands.

Bott, T. L., J. T. Brock, C. S. Dunn, R. J. Naiman, R. W. Ovink, and R. C. Petersen. 1985. Benthic community metabolism in four temperate stream systems: an inter-biome comparison and evaluation of the river continuum concept. Hydrobiologia 123:3-45.

Clapcott, J. E., and L. A. Barmuta. 2010. Forest clearance increases metabolism and organic matter processes in small headwater streams. Journal of the North American Benthological Society 29:546-561.

Fellows, C. S., S. E. Bunn, F. Sheldon, and N. J. Beard. 2009. Benthic metabolism in two turbid dryland rivers. Freshwater Biology 54:236-253.

Fellows, C. S., J. E. Clapcott, J. W. Udy, S. E. Bunn, B. D. Harch, M. J Smith, and P. M. Davies. 2006. Benthic metabolism as an indicator of stream ecosystem health. Hydrobiologia 572: 71-87.

Fellows, C. S., H. M. Valett, and C. N. Dahm. 2001. Wholestream metabolism in two montane streams: contribution of the hyporheic zone. Limnology and Oceanography 46:523531.

Fuss, C. L., and L. A. Smock. 1996. Spatial and temporal variation of microbial respiration rates in a blackwater stream. Freshwater Biology 36:339-349.

Hall, R. O., and J. J. Beaulieu. 2013. Estimating autotrophic respiration in streams using daily metabolism data. Freshwater Science 32:507-516. 
Hauer, F. R., and G. A. Lamberti. 2006. Methods in stream ecology. $2^{\text {nd }}$ edition. Academic Press, Amsterdam, The Netherlands.

Hedin, L. O. 1990. Factors controlling sediment community respiration in woodland stream ecosystems. Oikos 57:94-105.

Houser, J. N., P. J. Mulholland, and K. O. Maloney. 2005. Catchment disturbance and stream metabolism: patterns in ecosystem respiration and gross primary production along a gradient of upland soil and vegetation disturbance. Iournal of the North American Benthological Society 24:538-552.

Jones, J. I., A. L. Collins, P. S. Naden, and D. A. Sear. 2011. The relationship between fine sediment and macrophytes in rivers. River Research and Applications 28:1006-1018.

Kaenel, B. R., H. Buehrer, and U. Uehlinger. 2000. Effects of aquatic plant management on stream metabolism and oxygen balance in streams. Freshwater Biology 45:85-95.

Kleeberg, A., J. Köhler, T. Sukhodolova, and A. Sukhodolov. 2010. Effects of aquatic macrophytes on organic matter deposition, resuspension and phosphorus entrainment in a lowland river. Freshwater Biology 55:326-345.

Koopmans, D. J., and P. Berg. 2015. Stream oxygen flux and metabolism determined with the open water and aquatic eddy covariance techniques. Limnology and Oceanography 60:13441355.

Lampert, W. 1984. The measurement of respiration. Page 413468 in J. A. Downing and F. H. Rigler (editors). A manual on methods for the assessment of secondary productivity in fresh waters. $2^{\text {nd }}$ edition. Blackwell Scientific, Oxford, UK.

Leggieri, L., C. Feijoó, A. Giorgi, N. Ferreiro, and V. Acuña. 2013. Seasonal weather effects on hydrology drive the metabolism of non-forest lowland streams. Hydrobiologia 716:47-58.

Madsen, J. D., M. S. Adams, and P. Ruffier. 1988. Harvest as a control of sago pondweed (Potamogeton pectinatus L.) in Badfish Creek, Wisconsin: frequency, efficiency and its impact on stream community oxygen metabolism. Journal of Aquatic Plant Management 26:20-25.

Marzolf, E. R., P. J. Mulholland, and A. D. Steinman. 1994. Improvements to the diurnal upstream-downstream dissolved oxygen change technique for determining whole-stream metabolism in small streams. Canadian Journal of Fisheries and Aquatic Sciences 51:1591-1599.

Marzolf, E., P. Mulholland, and A. D. Steinman. 1998. Reply: Improvements to the diurnal upstream-downstream dissolved oxygen change technique for determining whole-stream metabolism in small streams. Canadian Journal of Fisheries and Aquatic Sciences 55:1786-1787.

Minshall, G. W., R. C. Petersen, T. L. Bott, C. E. Cushing, K. W. Cummins, R. L. Vannote, and J. R. Sedell. 1992. Stream ecosystem dynamics of the Salmon River, Idaho: an $8^{\text {th }}$-order system. Journal of the North American Benthological Societv 11:111-137.

Mulholland, P. J. , C. S. Fellows, J. L. Tank, N. B. Grimm, J. R. Webster, S. K. Hamilton, E. Martí, L. Ashkenas, W. B. Bowden, W. K. Dodds, W. H. McDowell, M. J. Paul, and B. J.
Peterson. 2001. Inter-biome comparison of factors controlling stream metabolism. Freshwater Biology 46:1503-1517.

O'Brien, J. M., J. L. Lessard, D. Plew, S. E. Graham, and A. R. McIntosh. 2014. Aquatic macrophytes alter metabolism and nutrient cycling in lowland streams. Ecosystem 17:405-417.

Odum, H. T. 1956. Primary production in flowing waters. Limnology and Oceanography 1:102-117.

Owens, M. 1974. Measurements on non-isolated natural communities in running waters. Pages 111-119 in R. A. Vollenweider (editor). A manual on methods for measuring primary production in aquatic environments. Blackwell Scientific, Oxford, UK.

Owens, M., R. W. Edwards, and J. W. Gibbs. 1964. Some reaeration studies in streams. Limnology and Oceanography 18: 306-310.

Prahl, C., E. Jeppesen, K. Sand-Jensen, and T. Moth-Iversen. 1991. A continuous-flow system for measuring in vitro oxygen and nitrogen metabolism in separate stream communities. Freshwater Biology 26:495-506.

Pomazkina, G., L. Kravtsova, and E. Sorokovikova. 2012. Structure of epiphyton communities on Lake Baikal submerged macrophytes. Limnological Review 12:19-27.

Reid, M. A., M. C. Thoms, and F. J. Dyer. 2006. Effects of spatial and temporal variation in hydraulic conditions on metabolism in cobble biofilm communities in an Australian upland stream. Journal of the North American Benthological Society 25:756-767.

Rier, S. T., and D. K. King. 1996. Effects of inorganic sedimentation and riparian clearing on benthic community metabolism in an agriculturally-disturbed stream. Hydrobiologia 339:111-121.

Sand-Jensen, K. 1998. Influence of submerged macrophytes on sediment composition and near-bed flow in lowland streams. Freshwater Biology 39:663-679.

Thyssen, N., M. Erlandsen, E. Jeppesen, and C. Ursin. 1987. Reaeration of oxygen in shallow, macrophyte rich streams. I. Determination of the reaeration coefficient. Internationale Revue der gesamten Hydrobiologie und Hydrographie 72:405-429.

Tunca, H., T. Ongun Sevíndík, D. N. Bal, and S. Arabaci. 2014. Community structure of epiphytic algae on three different macrophytes at Acarlar floodplain forest (northern Turkey). Chinese Journal of Oceanology and Limnology 32:845-857.

Van, T. K., W. T Haller, and G. Bowes. 1976. Comparison of the photosynthetic characteristics of three submersed aquatic plants. Plant Physiology 58:761-768.

Webster, J. R., and H. M. Valett. 2006. Solute dynamics. Pages 169185 in F. R. Hauer and G. A. Lamberti (editors). Methods in stream ecology. Academic Press, Amsterdam, The Netherlands.

Young, R. G., A. D Huryn, E. R. Marzolf, P. J. Mulholland, and A. D. Steinman. 1998. Comment: Improvements to the diurnal upstream-downstream dissolved oxygen change technique for determining whole-stream metabolism in small streams. Canadian Journal of Fisheries and Aquatic Sciences 55:1784-1787. 